https://doi.org/10.18778/0208-6107.36.01

\title{
KRYTYKA ARTYSTYCZNA DWUDZIESTOLECIA MIĘDZYWOJENNEGO. MIĘDZY ESTETYKĄ FILOZOFICZNĄ I SZTUKĄ NOWOCZESNĄ (WPROWADZENIE)
}

Teksty zebrane tym tomie są rozszerzoną i zmodyfikowaną wersją referatów zaprezentowanych w Muzeum Sztuki w Łodzi w dniach 22-23 lutego 2018 roku, w ramach konferencji Krytyka artystyczna dwudziestolecia międzywojennego. Między estetyka filozoficzna a sztuka nowoczesna ${ }^{1}$. W poprzednim, 35 numerze „Folia Philosophica. Ethica - Aesthetica - Practica”, zamieszczone zostały teksty z tej konferencji poświęcone ważnym postaciom życia filozoficznego i krytyki artystycznej w Polsce międzywojennej, takim jak Mieczysław Wallis, Roman Ingarden, Zofia Lissa i Stefania Zahorska. Niniejszy tom, będący dopełnieniem tamtego, w przeważającej mierze skupia się na postaci jednej autorki, której krytyczne pisarstwo i filozoficzne inspiracje wciąż wydają się w Polsce słabo rozpoznane - na refleksji estetycznej Debory Vogel (1902-1942). $\mathrm{Z}$ wieloaspektowego oeuvre tej pisarki, poetki, krytyczki i filozofki wydobyte zostały tu przede wszystkim te zagadnienia, które wiążą się z filozoficznym namysłem nad nowoczesną kondycją i doświadczeniem, oraz refleksją nad znaczeniami i funkcją nowoczesnej sztuki.

Głęboki związek pisarstwa Vogel z doświadczeniem nowoczesności - niekoniecznie tej najbardziej spektakularnej i zorientowanej przyszłościowo, lecz raczej nowoczesności marginesów i peryferii, uwidoczniony został w ramach pokazywanej w Muzeum Sztuki na przełomie 2017 i 2018 roku wystawy Montaże. Debora Vogel i nowa legenda miasta ${ }^{2}$. Ekspozycja ta, prezentująca szeroki wybór prac lwowskich twórców z grupy Artes oraz Grupy Krakowskiej, osadzała ich działalność w kontekście współczesnej miejskiej ikonosfery oraz lokalnej topografii Lwowa, z którą związana była też twórczość Vogel. Przez swoisty montaż obrazów, tekstów i muzycznych fragmentów podkreślała ona związek nowych form artystycznych z warunkami percepcji znamiennymi dla przestrzeni nowoczesnego miasta. Życie i pisarstwo Debory Vogel stanowiły

\footnotetext{
${ }^{1}$ Kuratorem konferencji był Paweł Polit, jej koordynatorką była Agata Szynkielewska.

${ }^{2}$ Montaze. Debora Vogel $i$ nowa legenda miasta (27.10.2017-4.02.2018), kuratorzy: Andrij Bojarov, Paweł Polit, Karolina Szymaniak, Muzeum Sztuki w Lodzi, https://msl.org.pl/montaze-debora-vogel-i-nowa-legenda-miasta/ Zob. także katalog wystawy: Montaże. Debora Vogel i nowa legenda miasta, red. Andrij Bojarov, Paweł Polit, Karolina Szymaniak, Muzeum Sztuki w Łodzi, Łódź 2017.
} 
kluczowy punkt odniesienia tej wystawy, prezentującej się jako układ miejsc, scen i obserwacji zapisanych w jej twórczej biografii. Jej własny kosmopolityzm i wielojęzyczność (Vogel pisała w języku jidysz, hebrajskim i polskim, sprawnie posługiwała się też niemieckim), zagraniczne podróże i zapiski z dalekich miast, miały poniekąd analogię w zagranicznych (głównie paryskich) wędrówkach i inspiracjach artystów Artesu i Grupy Krakowskiej. W jednym i drugim przypadku świadomość zmian zachodzących w wielkich centrach sztuki szła jednak $\mathrm{w}$ parze $\mathrm{z}$ uwrażliwieniem na lokalne idiomy, $\mathrm{z}$ poszukiwaniem własnego języka, nie powielającego gotowych formuł, lecz otwartego na specyfikę zjawisk sensualnie i mentalnie zakorzenionych w innej, lokalnej czasoprzestrzeni ${ }^{3}$. Języka, który wskutek swojej odrębności bywa nieoczywisty i nieprzystępny, ale też odkrywczy i oryginalny.

$\mathrm{Na}$ gruncie krytyki sztuki najbardziej znanymi tekstami Vogel są zapewne jej komentarze $z$ lat 30. dotyczące montażu i fotomontażu - korespondujące ze współczesnymi poszukiwaniami twórców Artesu i odwołujące się wprost do ich prac. W teoretycznej refleksji Vogel, jak i w zbieżnych z nią jej własnych poetyckich eksperymentach, twórcy tej grupy, na ogół nieskorzy do teoretyzowania, mogli znaleźć uzasadnienie i uprawomocnienie swoich artystycznych poszukiwań. Pokrewieństwo między koncepcjami Vogel a twórczością lwowskich artystów wyrażało się też w zainteresowaniu estetyką małomiasteczkowej tandety i kiczu, w swoistej czułości okazywanej formom ,upadłej”, zdegradowanej materii. Krytyczna refleksja Vogel wykraczała jednak daleko poza ten kontekst, obejmując różne nurty we współczesnej sztuce i literaturze, oraz pozostając $\mathrm{w}$ dialogu $\mathrm{z}$ aktualną filozofią i estetyką niemiecką, z którą była dobrze obeznana. Oryginalność perspektywy myślowej Vogel zasadza się na ścisłym powiązaniu zagadnień estetycznych i epistemicznych, skupieniu nie tyle na kwestiach estetycznego wartościowania, co na problematyce kształtowania artystycznego i postrzegania. Jako autorka rozbudowanej rozprawy doktorskiej Znaczenie poznawcze sztuki u Hegla i jej modyfikacje u J. Kremera (1926), Vogel, zdeklarowana heglistka, czerpała inspirację twórczą oraz energię życiową z ,abstrakcyjnej wiedzy o dialektyce”, która - jak napisała w liście do Brunona Schulza - „pomaga w ostatecznej rozpaczy i beznadziejności”4. W sprawach współczesnej sztuki nie zajmowała jednoznacznych doktrynalnych pozycji. Uważnie obserwowała i komentowała nie tylko twórczość artystów z Artesu i Grupy Krakowskiej, ale także Katarzyny Kobro i Władysława

${ }^{3} \mathrm{Na}$ temat „regionalnego modernizmu” w twórczości Henryka Strenga, przekładającego Légerowskie formuły na „rdzenne” wizerunki lwowskich przedmieść por. Piotr Słodkowski, Modernizm żydowsko-polski. Henryk Steng/Marek Włodarski a historia sztuki, Instytut Badań Literackich, Warszawa 2019, s. 96-205.

${ }^{4}$ Debora Vogel, list do Brunona Schulza z 21 maja 1938, w: Bruno Schulz, Księga listów, zebrał i przygotował do druku Jerzy Ficowski, uzup. Stanisław Danecki, Słowo/Obraz Terytoria, Gdańsk 2016, s. 262. 
Strzemińskiego; była zwolenniczką teorii czystej formy Stanisława Ignacego Witkiewicza, przeciwniczką naturalizmu, a zarazem rzeczniczką nowej architektury i rozwoju sztuk stosowanych.

Zasady estetyki Vogel czytelne są również w jej utworach poetyckich - wierszach opublikowanych w jidysz tomie Tog-figurn $(1930)^{5}$, obrazujących geometrię tytułowych „figur dnia”, oraz w montażach ułożonych w książce Akacje kwitna, rejestrujących koloryt przestrzeni miejskiej oraz monotonię codziennego funkcjonowania ${ }^{6}$. Oba zbiory ilustrowane są nawiązującymi do surrealizmu pracami Henryka Strenga [od 1944 roku posługującego się nazwiskiem Marek Włodarski], artysty związanego z grupą Artes, konfrontującymi struktury architektoniczne $\mathrm{z}$ formami organicznymi. Pisarka podkreśliła odrębność wizji manifestującej się w ilustracjach Strenga wobec brzmienia jej własnego tekstu; nie są one „dosłownym przetłumaczeniem tekstu, ale w oryginalny, zgodny z każdorazową koncepcją formy, sposób ujęty i zobrazowany klimat utworu czy pojedynczej sytuacji" ${ }^{\prime}$. Wybrane prace tego artysty z kolekcji Muzeum Sztuki w Łodzi posłużyły w niniejszym numerze pisma jako punkty odniesienia dla rozważań dotyczących myśli estetycznej Vogel.

Refleksja teoretyczna Vogel wiąże się z diagnozą fazy rozwoju sztuki abstrakcyjnej, w której już nie rozpoznawalne kształty rzeczy, ale „same napięcia i kierunki mas w ruchu" stały się właściwymi przedmiotami namysłu artystów ${ }^{8}$. $\mathrm{Z}$ ową późną fazą abstrakcji wiązała ona nadzieję na przeniesienie praktyk artystycznych na zupełnie nowy poziom rozumienia medium artystycznego i sposobu angażowania odbiorcy. Rozważała możliwość wypełnienia składni nowoczesnego malarstwa i rzeźby treścią życiową, w tym odniesieniami do kwestii społecznych i politycznych.

Wiele uwagi Vogel poświęciła zasadom unizmu Katarzyny Kobro i Władysława Strzemińskiego. Dwa jej teksty zawierają przenikliwe sformułowania wiążące koncepcję jednolitej struktury dzieła $\mathrm{z}$ centralnym dla jej własnej

\footnotetext{
${ }^{5}$ Debora Vogel, Tog-figurn, Lemberg 1930. Przekłady wybranych utworów z tego tomu pomieszczone zostały w książce Karoliny Szymaniak Być agentem wiecznej idei. Przemiany pogladów estetycznych Debory Vogel, Towarzystwo Autorów i Wydawców Prac Naukowych Universitas, Kraków 2006.

${ }^{6}$ Montaże te ukazały się najpierw w jidysz jako Akacjes Blinen, Lwów-Warszawa, 1935, następnie w języku polskim jako Akacje kwitną, Towarzystwo Wydawnicze „Rój”, Warszawa 1936. Drugie wydanie polskie: Akacje kwitna. Montaże, red. Piotr Paziński, Wydawnictwo Austeria, Kraków 2006.

${ }^{7}$ Debora Vogel, Henryk Streng - malarz konstruktywizmu (1937), „Nasza Opinia” 1937, nr 96, s. 6. Również w tomie Montaże. Debora Vogel..., s. 366-367.

${ }^{8}$ Por. Debora Vogel, O sztuce abstrakcyjnej, w: Montaże. Debora Vogel i nowa legenda miasta, s. 371 (pierwodruk: „Wiadomości Literackie” 1934, nr 25, s. 6).
} 
myśli pojęciem statyki ${ }^{9}$. Autorka dostrzega nową jakość, która pojawiła się w teorii unizmu; omawia postulowaną w niej kwalifikację organicznej jedności dzieła $\mathrm{w}$ kategoriach integrowania go z miejscem. Miejsce pojmuje przy tym - podobnie jak Kobro i Strzemiński - w duchu konstruktywizmu; pisze, że „w każdej swojej fazie, w każdym przekroju i w każdym fragmencie powtarza taka rzeźba strukturę statyczną i to niweluje wszelki dynamizm"10. W jej wykładni rzeźba unistyczna aktualizuje określony sposób artykulacji przestrzeni; nie jest ona „kształtowaniem bryły, ale przestrzeni, (...) jest granicą przestrzeni” ${ }^{11}$. Mimo tych aprobatywnych uwag, Vogel rozpoznaje jednak także ograniczenia koncepcji Kobro i Strzemińskiego; kształtowana w realiach społecznych i politycznych lat trzydziestych XX wieku, rzeźba unistyczna, jak twierdzi, „Wymaga skonfrontowania proponowanego elementu kompozycyjnego $\mathrm{z}$ elementem rzeczy i zużytkowania elementu życiowego dla swych założeń formalnych"12. Postulowany przez Vogel unistyczno-montażowy model dzieła nie doczekał się realizacji; za jego aproksymacje, które inspirowały rozważania Vogel, można uznać niektóre prace malarskie artystów z Grupy Krakowskiej: Saszy Blondera, Leopolda Lewickiego czy Stanisława Osostowicza - obrazy wiążące unistyczną składnię $\mathrm{z}$ aluzyjnymi, syntetycznymi $\mathrm{w}$ formie, lecz wymownymi treściowo odniesieniami do rzeczywistości społecznej lat trzydziestych w Polsce. Autorka nie zdążyła nadać swoim antycypacjom dotyczącym społecznego oddziaływania sztuki, formułowanym w warunkach kryzysu ekonomicznego i politycznego lat trzydziestych, charakteru rozbudowanej propozycji teoretycznej. Jej prace nad dopracowaniem tych koncepcji przerwał wybuch wojny i jej przedwczesna śmierć.

Teksty prezentowane w tym tomie koncentrują się na różnych aspektach powiązań, jakie Debora Vogel w swojej estetyce widziała między rzeczywistością sztuki a światem życia. Anna Maja Misiak rekonstruuje teoretyczne koncepcje Vogel, sytuując je w kontekstach współczesnej niemieckiej filozofii i krytyki sztuki, uwidaczniając m.in. jej związki z koncepcjami Lu Märten i Alferda Behne, a także inspiracje czerpane $\mathrm{z}$ witalistycznych, biosemiotycznych idei Jakoba von Uexkülla. To właśnie koncepcje tego ostatniego - silnie oddziałujące na współczesną filozofię, na rozwój refleksji fenomenologicznej i na współczesnych artystów, utwierdzały Vogel w jej przekonaniu o organicznym związ$\mathrm{ku}$ życiowych funkcji i form postrzegania z formami artystycznymi. Potrzeba nowych form jest w tym kontekście organiczną potrzebą samego życia, kwestią

\footnotetext{
${ }^{9}$ Por. Debora Vogel, Kompozycja przestrzeni, w: Montaże... (pierwodruk: „Tygodnik Artystów”, 12 stycznia 1935, s. 3; pierwsza wersja tego tekstu ukazała się na łamach pisma „Opinia” 1933, nr 27) oraz eadem, O sztuce abstrakcyjnej...

${ }^{10}$ Debora Vogel, Kompozycja przestrzeni, s. 306.

${ }^{11}$ Ibidem, s. 305.

${ }^{12}$ Ibidem, s. 306.
} 
jego dialektycznych przekształceń i rozwoju. Praktycznym wyrazem tych założeń były, jak zauważa badaczka, zainteresowania Vogel w zakresie edukacji artystycznej i jej własna działalność społeczna i wychowawcza.

Artykuł Anastasyi Luybas wydobywa jeden, dotychczas mało eksponowany wątek koncepcji Vogel, jakim jest rola powracającego w jej tekstach pojęcia „fantastyki”, odmienianego w różnych wariantach i łączonego zarówno z bogactwem wyobrażeń, barw i form, jak i z estetyką szarości i monotonii. Opisywana przez Vogel, znamienna dla nowoczesności „fantastyka geometrii”, prostoty i rzeczowości, jest $\mathrm{w}$ jej rozumieniu nie tyle stylem, co swoistą atmosferyczną otoczką, poetyckim wytworem ducha (w znaczeniu greckiego terminu poiesis jako wytwarzania) - subiektywnie uchwyconą fizjonomiczną prawdą epoki. Idea „fantastyki” jako cechy samego myślenia i postrzegania jawi się w tym sensie jako centralna dla estetyki i metody pisarskiej Vogel; według Luybas jest ona pokrewna Heideggerowskiej koncepcji „wydarzania się" prawdy w dziele sztuki oraz myśleniu samego bycia poza określonością bytów - „myśleniu fantastycznemu”, zgodnie z określeniem Catherine Malabou.

Pisząc o nowej sztuce, Vogel daleka była od iluzji progresywizmu, charakterystycznych dla awangardowej retoryki. Bliższy był jej „,iryzm”, „fatalizm i smutek”, cechujący obrazy Henryka Strenga, gdzie ,upodobnione do maszyny” ciało ludzkie ukazuje swój „ostateczny sens (...), którym jest nieporadność i rezygnacja" ${ }^{13}$. Streng „w miejsce egotycznego dynamizmu przeżycia wprowadził jedynie obiektywne, odindywidualizowane przekroje życia ludzkiego"14. Iwona Lorenc, czytając Vogel ze współczesnej perspektywy jako refleksyjną interpretatorkę nowoczesnego miasta-spektaklu, dostrzega w niej autorkę, która poniekąd wyprzedziła swój czas - antycypowała refleksję, która miała dopiero nadejść. Rozwijana i komentowana przez nią praktyka twórcza akcentująca momenty oderwanych przeżyć (Erlebnisse), pozostałych po nowoczesnym rozpadzie doświadczenia, okazuje się przy tym produktywnym sposobem artykułowania nowego - znamiennego dla ponowoczesności - typu przeżywania, zdanego na symultanizm i zdarzeniowość, odległego od linearnej i kumulatywnej koncepcji czasu, a otwartego na to co anachroniczne.

Dwa pozostałe artykuły dotyczą zjawisk w polskiej krytyce sztuki okresu dwudziestolecia częściowo powiązanych lub paralelnych względem twórczości Vogel. Krytyka Jana Brzękowskiego, zwłaszcza jego komentarze dotyczące sztuk wizualnych, podobnie jak jej koncepcje pozostawały otwarte na impulsy różnych awangardowych nurtów - surrealizmu i konstruktywizmu, między którymi starał się być mediatorem. W analogiczny też sposób Brzękowski akcentował konstruktywny i prospołeczny wymiar nowoczesnej sztuki (rolę „formalnej budowy”), dowartościowując zarazem jej wymiar metaforyczny i aluzyjny.

\footnotetext{
${ }^{13}$ Debora Vogel, Henryk Streng - malarz konstruktywizmu, w: Montaże..., s. 365.

${ }^{14}$ Ibidem.
} 
Artykuł Renaty Piątkowskiej, oparty na analizie prasy z końca lat dwudziestych XX wieku, rekonstruuje toczący się wówczas spór wokół pojęcia sztuki żydowskiej - jej odrębności i potrzeby tworzenia dla niej odrębnych ram. Odnotowując narastające nacjonalistyczne i antysemickie tendencje, badaczka ukazuje ewolucję, jaką przeszła sama idea „sztuki żydowskiej”, począwszy od jej pierwszych, afirmatywnych i postulatywnych artykulacji. Sama Debora Vogel dystansowała się wobec etnicznego i narodowego separatyzmu na gruncie sztuki, jednak to właśnie utrwalone językowe i kulturowe podziały stały się jednym z powodów, dla których jej pisarstwo - związane w znacznej mierze $\mathrm{z}$ językiem jidysz - odkrywane jest $\mathrm{z}$ tak znacznym opóźnieniem. Mamy nadzieję, że niniejszy tom, będący przedłużeniem toczących się badań, przyczyni się do pełniejszego jej poznania i rozumienia.

Agnieszka Rejniak-Majewska

Pawet Polit 